\title{
Correction to: Plant species- and stage-specific differences in microbial decay of mangrove leaf litter: the older the better?
}

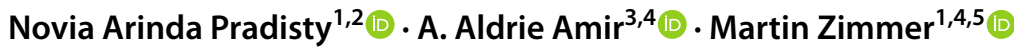

Published online: 15 March 2021

(c) The Author(s) 2021

\section{Correction to: Oecologia}

https://doi.org/10.1007/s00442-021-04865-3

Authors would like to correct the errors in their publication.

The original article has been corrected.

Incorrect Supplementary Information (ESM2) deleted now.

The line "A color version of this figure is available online" to be deleted from all figure captions since the color figures in print version is not charged now.

Missing references for the text citations were updated here

\section{Alongi, 2002}

Alongi DM (2002) Present State and Future of the World's Mangrove Forests. Environ Conserv 29:331-349. https://doi.org/10.1017/S0376892902000231

\section{Alongi and Dixon, 2000}

Alongi DM, Dixon P (2000) Mangrove primary production and above-and below-ground biomass in Sawi Bay, southern Thailand. Phuket Mar Biol Cent Spec Publ 22:31-38.

The original article can be found online at https://doi.org/10.1007/ s00442-021-04865-3.

Novia Arinda Pradisty

novia.arinda@kkp.go.id

1 Faculty 2 Biology/Chemistry, Universität Bremen, Bremen, Germany

2 Institute for Marine Research and Observation, Ministry of Marine Affairs and Fisheries, Negara, Bali, Indonesia

3 Institute for Environment and Development (LESTARI), Universiti Kebangsaan Malaysia, Bangi, Selangor, Malaysia

4 IUCN SSC Mangrove Specialist Group, London, England

5 Leibniz Centre for Tropical Marine Research, ZMT-GmbH, Bremen, Germany
Arfi et al. 2012

Arfi Y, Buée M, Marchand C, et al (2012) Multiple markers pyrosequencing reveals highly diverse and host-specific fungal communities on the mangrove trees Avicennia marina and Rhizophora stylosa. FEMS Microbiol Ecol 79:433-444. https://doi.org/10.1111/j.1574-6941.2011.01236.x

Krishna and Mohan, 2017

Krishna MP, Mohan M (2017) Litter decomposition in forest ecosystems: a review. Energy, Ecol Environ 2:236-249. https://doi.org/10.1007/s40974-017-0064-9

Murdiyarso et al. 2015

Murdiyarso D, Purbopuspito J, Kauffman JB, et al (2015) The potential of Indonesian mangrove forests for global climate change mitigation. Nat Clim Chang 5:1089-1092. https ://doi.org/10.1038/nclimate2734

Quadros et al. 2019

Quadros AF, Nordhaus I, Reuter H, Zimmer M (2019) Modelling of mangrove annual leaf litterfall with emphasis on the role of vegetation structure. Estuar Coast Shelf Sci 218:292-299. https://doi.org/10.1016/j.ecss.2018.12.012

Open Access This article is licensed under a Creative Commons Attribution 4.0 International License, which permits use, sharing, adaptation, distribution and reproduction in any medium or format, as long as you give appropriate credit to the original author(s) and the source, provide a link to the Creative Commons licence, and indicate if changes were made. The images or other third party material in this article are included in the article's Creative Commons licence, unless indicated otherwise in a credit line to the material. If material is not included in the article's Creative Commons licence and your intended use is not permitted by statutory regulation or exceeds the permitted use, you will need to obtain permission directly from the copyright holder. To view a copy of this licence, visit http://creativecommons.org/licenses/by/4.0/. 